UDC 539.3

DOI: https://doi.org/10.20535/0203-3771402020248782

S. I. Trubachev ${ }^{1}$, candidate of technical sciences, O. N. Alexeychuck ${ }^{2}$, candidate of technical sciences

\title{
THE STRESS-STRAIN STATE OF GONDOLA MOUNTING BRACKET OF A TRANSPORT AIRCRAFT
}

Ua Кронштейн вікорістовується для кріплення гондоли, что є важлівою частина сілової установки літака. Гондола постійно піддається великим навантаження під час запуску двигуна, у польоті, під час зльоту та посадки. Тому міцність кронштейнів ее кріплення має дуже важліве значення. Геометрична $3 D$ модель побудовали у програмі SOLIDWORKS та імпортована для подалі розрахунків у ANSYS. У програмі булу створена сітка тетраїдної форми елементів. Завдяк отріманій сітці скінченіх елементів робимо розрахунок напружено деформівного стану. За результатами дослідження надаються коментарі по зміні геометричних та масових параметрів кронштейна.

Ru Кронштейн используется для крепления гондолы и является важной частью силовой установки самолета. Гондола постоянно подвергается большим нагрузкам при запуске двигателя, во время взлета и посадки. Поэтому прочность кронштейнов ее крепления имеет очень важное значение. Геометрическая $3 D$ модель построена в программе SOLIDWORKS и импортирована для дальнейших расчетов в ANSYS. В программе была создана сетка тетраидной формы элементов. Благодаря полученной сетке конечных элементов делаем расчет напряженно деформированного состояния. По результатам исследования предоставляются комментарии по изменению геометрических и массовых параметров кронштейна.

\section{Introduction}

Power schemes of gondolas can be of two types. The gondola of a semimonococcal design consists of the rigid panels forming the closed power cover [1]. This design absorbs air loads and mass forces and it's attached to the glider or engine suspension [2,3]. Loads from the engine are transferred to the glider (directly to the wing, fuselage or pylon). The frame construction differs in that it has a power frame. Gondola of this design also takes the load from the engine and transmits it to the glider. The fig. 1 shows the turbojet gondola on a vertical pylon under the wing. This figure shows the similarity of the designs of the gondola and fuselage, pylon and wing. A feature of the design and layout of the turbojet gondola is the specific configuration of the front part, which is due to the presence of the fairing of the screw sleeve and the reducer.

\footnotetext{
${ }^{1}$ Igor Sikorsky Kyiv polytechnic institute

${ }^{2}$ Igor Sikorsky Kyiv polytechnic institute
} 


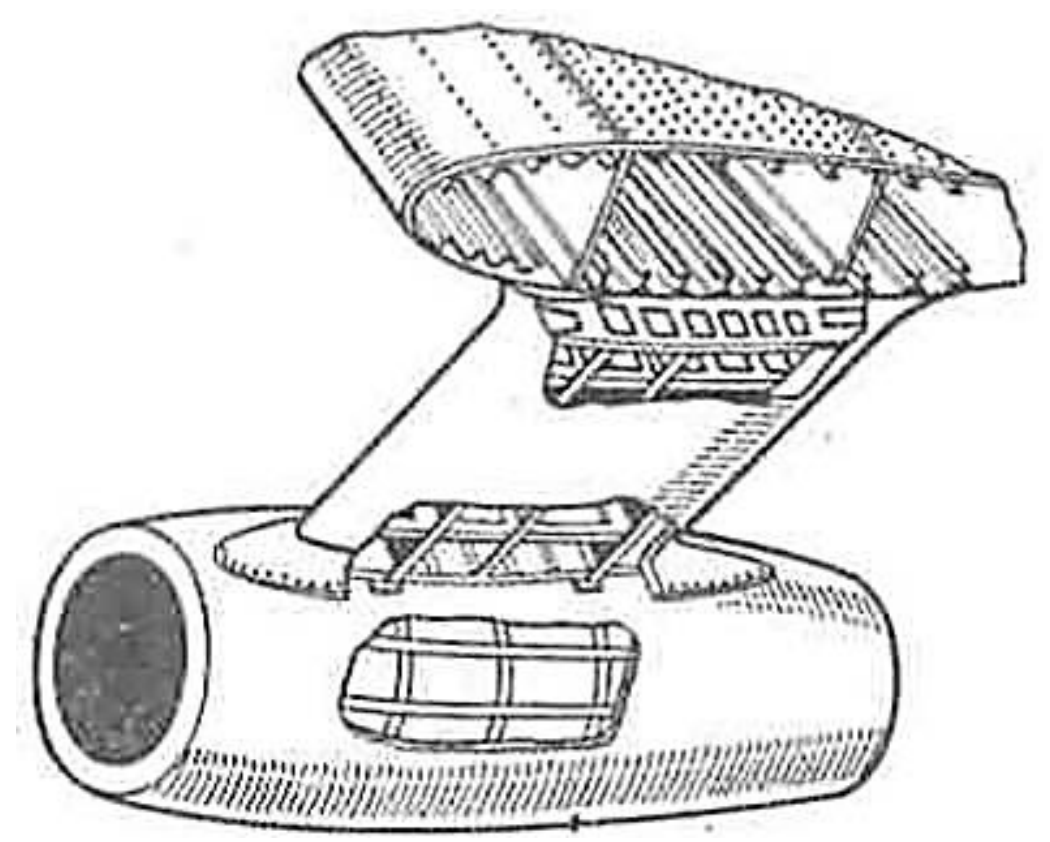

Fig. 1. Turbojet gondola on a vertical pylon under the wing

Loads arising during the flight are transmitted through the brackets to the hood, which reduces their life and the life of the power plant as a whole. The increasing of resource and improving operational capabilities by unifying power plants is an urgent task.

\section{Statement and solution of the problem}

To solve the problem of determining the stress-strain state of the front support of the chassis, analytical methods are ineffective due to the complex geometry, so it is advisable to use numerical calculation methods [4-6]. To build a finite-dimensional model, three-dimensional finite elements in the form of a tetrahedron (fig. 2) were used, within which a linear displacement field is given:

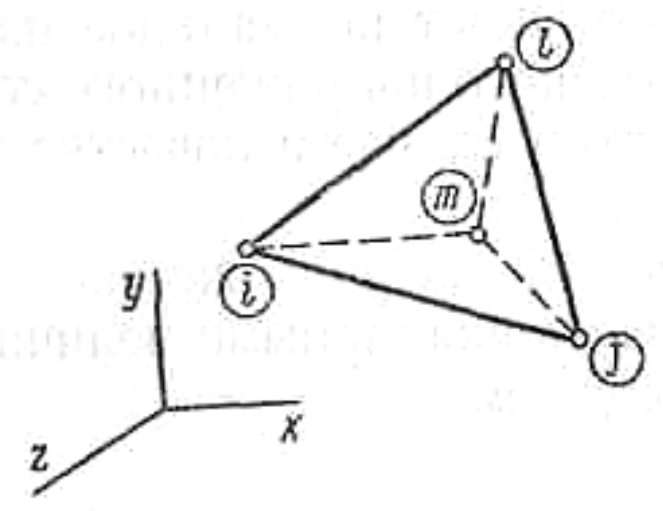

Fig. 2. A finite element of a tetrahedron

$$
\begin{aligned}
& u_{x}=f_{1}+f_{2} x+f_{3} y+f_{4} z ; \\
& u_{y}=f_{5}+f_{6} x+f_{7} y+f_{8} z ;
\end{aligned}
$$




$$
u_{z}=f_{9}+f_{10} x+f_{11} y+f_{12} z .
$$

where $f_{1} \ldots f_{12}$ are the arbitrary constants. Equating at nodal points $u_{x}, u_{y}, u_{z}$ to the corresponding nodal displacements, it is possible to express constants through nodal displacements $v^{e}$ and get the dependence in the form $u=\alpha v^{e}$. Using the usual procedure allows us to find the stiffness matrix of such an element. In the three-dimensional case, all six components of deformation are taken into account. Expressions for stresses inside each element in general have the form:

$$
\sigma^{(\mathrm{m})}=C^{(m)} \varepsilon^{(m)}+\sigma_{0}^{(\mathrm{m})} .
$$

Where $\mathrm{C}$ is the elastic matrix of the element $m$ (Hooke's matrix), and $\sigma_{0}^{(\mathrm{m})}$ is the initial tension in the middle element. In a structure, which consist of different materials, each element can have its own elastic matrix.

\section{Calculation of the stress-strain state of the bracket. The geometric model}

The geometric model of the bracket was built in accordance with the drawings of the part used on the aircraft in the computer-aided design system SOLIDWORKS. The model was exported in the program ANSYS (fig. 3)

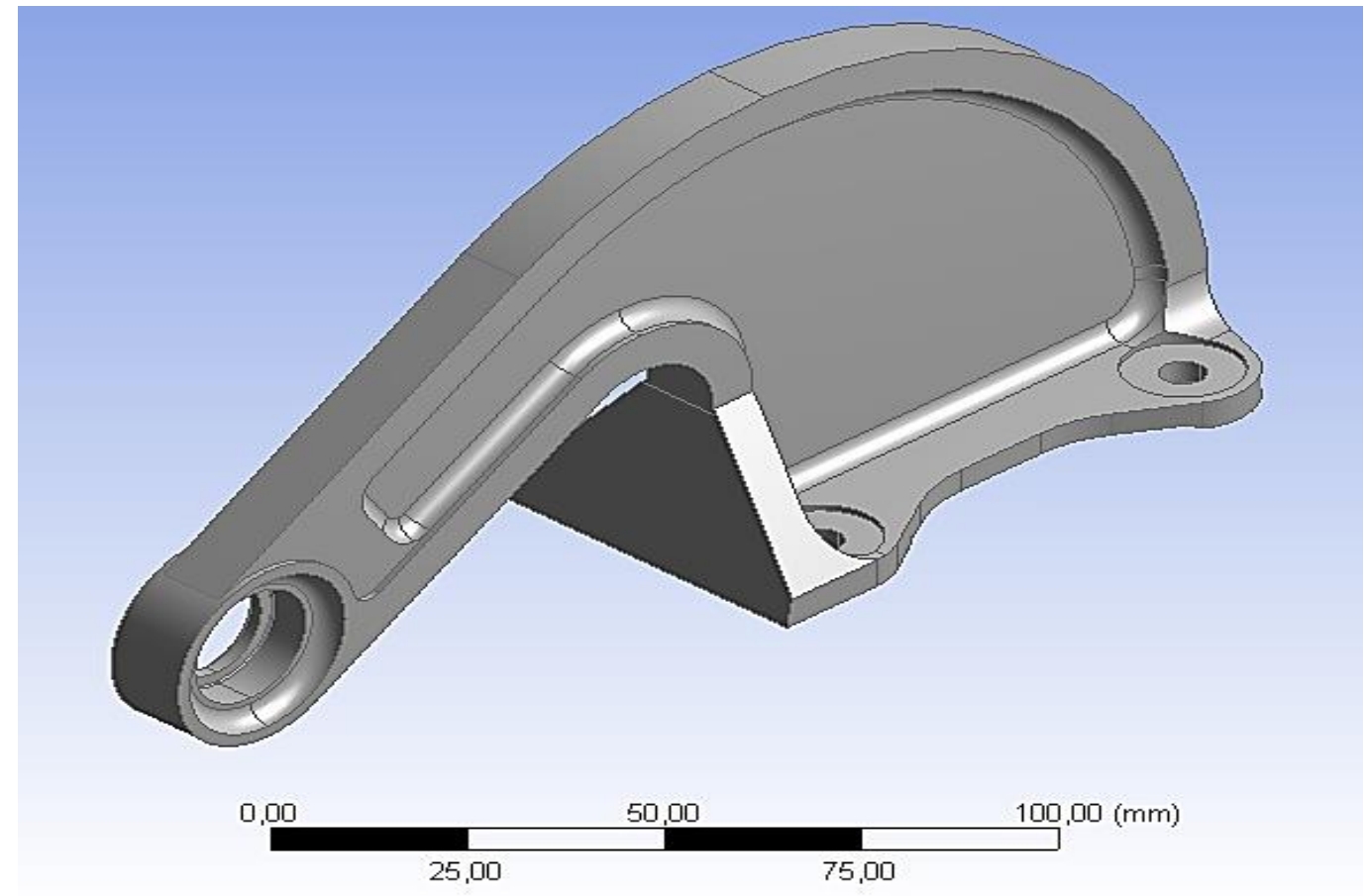

Fig. 3. Geometric model

As a result, a corresponding grid was created for the constructed geometry (fig. 4) by using tetrahedral finite element. It's used for creating a grid on models in which holes or ovals are an integral part. Ovality is often used in the manufacture of parts of complex shape so as not to form a stress concentrator. 
Механіка гіроскопічних систем

Therefore, in places of rounding for greater accuracy in this case, a large number of finite elements are used. The number of finite elements can be varied depending on the complexity of design and data accuracy.

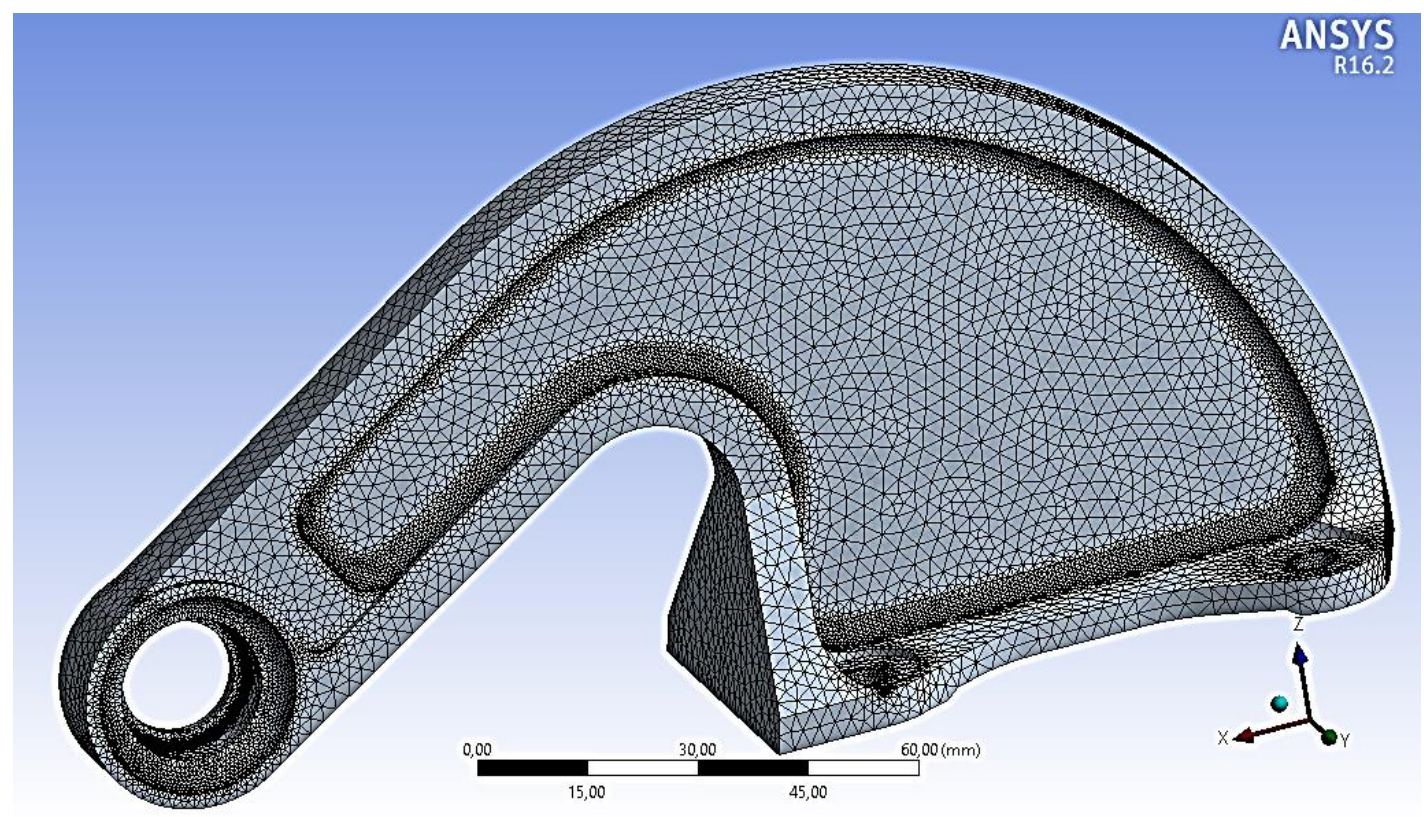

Fig. 4. Finite elements grid view

\section{Results}

The maximum displacement of the original part is $6,6411 \mathrm{~mm}$ at the end of the eyelet (Fig. 5,a). On the developed model it has a value of $6,5865 \mathrm{~mm}$ (Fig. 5, b).

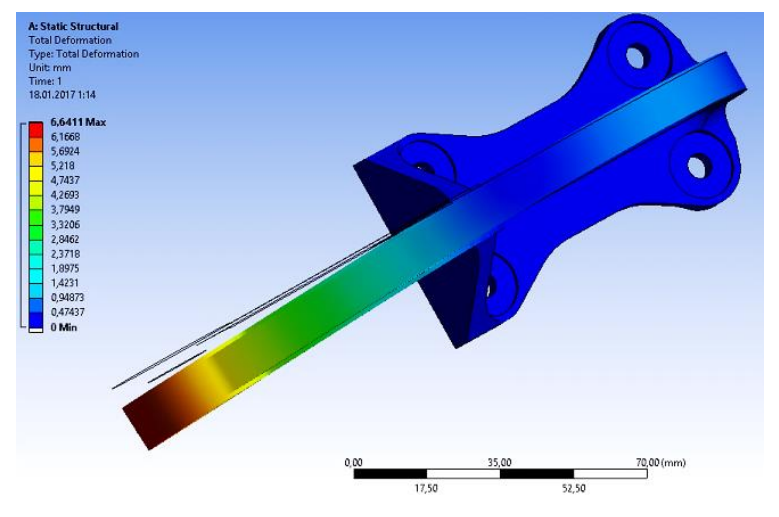

a)

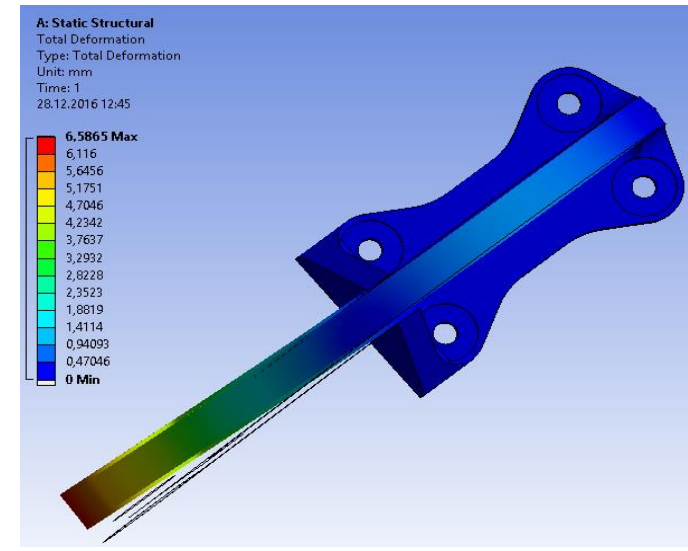

b)

Fig. 5. Displacements distribution

The elasticity zone is shown in fig. $6, a$, fig. $6, b$. 


\section{Механіка елементів конструкиій}

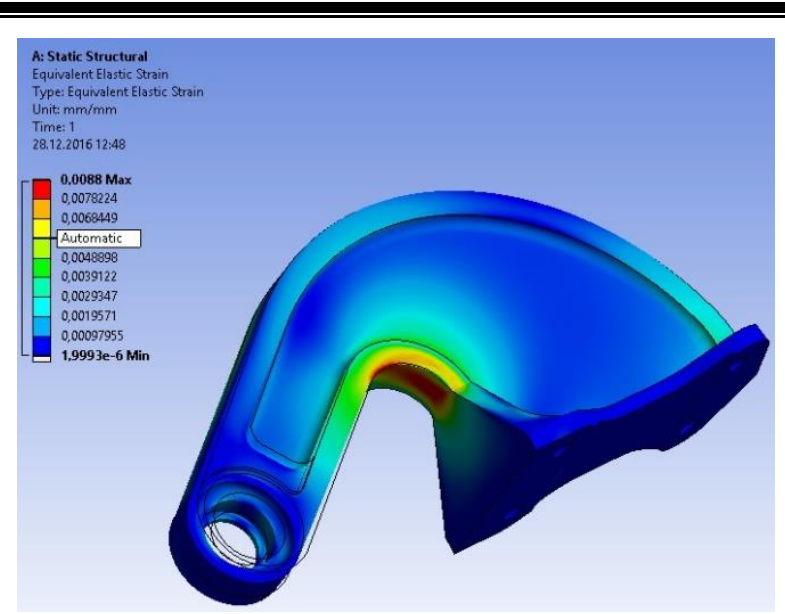

a)

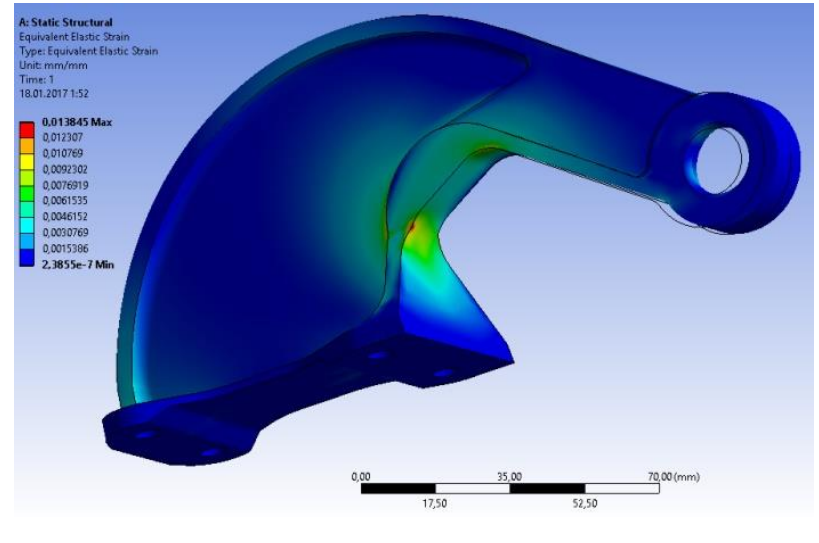

b)

Fig. 6. Elastic deformation

The most analysis codes make it possible to specify what results should be in the source data. In this case, choose to display all the results of the calculation. Interactive presentation of results connects finite element analysis and engineering representation. Having studied the color fill of the results, the deformation of the form, the animation of the motion of the model and the numerical results, we can draw the appropriate conclusions (fig.7, $a$, fig.7, $b$ ).

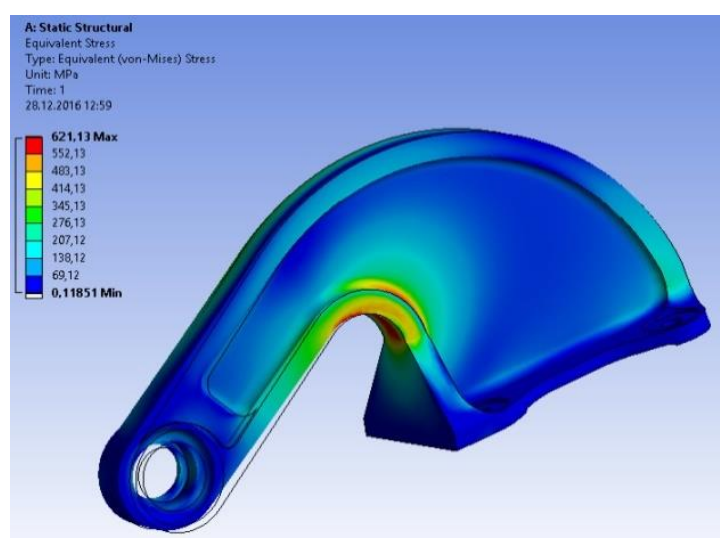

a)

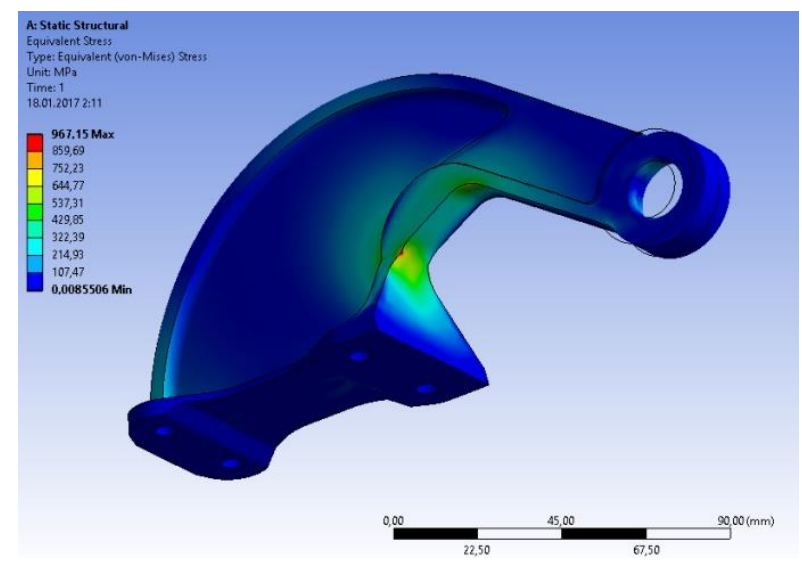

b)

Fig. 7. Equivalent loads according to Mises

As a result of the calculations, a comparative table 1 was created.

Table 1.

Comparison results

\begin{tabular}{lcc|c|}
\hline \multicolumn{1}{|c|}{ Criteria } & The original model & Developed model \\
\hline Mass, $g$ & 221 & 190 \\
Number of FE & 353411 & 327584 \\
Moving, $\mathrm{mm}$ & 6,64 & 6,58
\end{tabular}




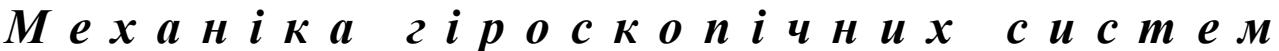

\begin{tabular}{l|c|c|}
\hline \multicolumn{1}{|c|}{ Criteria } & The original model & Developed model \\
\hline $\begin{array}{l}\text { Elastic deformation, } \\
\mathrm{mm} / \mathrm{mm}\end{array}$ & 0,013 & 0,008 \\
$\begin{array}{l}\text { Equivalent loads according } \\
\text { to Mises, MPa }\end{array}$ & 967,15 & 621,13 \\
\end{tabular}

\section{Conclusions}

The paper presents a method of calculating the load-bearing structures of the aircraft on the basis of numerical methods and modern programs. As a result of the stress-strain state analysis of the transport aircraft gondola bracket by the using of finite element method, the most dangerous, in terms of stresses, places were identified. The dependence of the stress-strain state of the gondola bracket from the influence of geometric parameters and operating loads were also determined, which allowed us to give recommendations for design optimization.

\section{References}

1. Чемерис О. М. Будівельна механіка машин. / О. М. Чемерис, В. А. Колодежний, С. І. Трубачев. - Київ,: КПІ ім. Ігоря Сікорського, 2017. $-258 \mathrm{c}$.

2. Нестеренко A. B. Розрахунок на міцність елемента системи керування транспортним літаком/ А. В. Нестеренко, С. І. Трубачев, С. Г. Кривова. // Матеріали міжнародної науково-технічної конференції молодих вчених та студентів «Іновації молоді-машинобудуванню» 2020, Київ, 19-20 травня 2020p.- КПІ імені Ігоря Сікорського http:// imm-mi.kpi.ua/imm 2020/paper/view paper $/ 21522$

3. Міменко Д. С. Напружено-деформований стан клепаного з"єднання конструкції, що складається 3 двох пластин/ Д. С. Міщенко, С. I. Трубачев // Матеріали міжнародної науково-технічної конференції молодих вчених та студентів «Іновації молоді-машинобудуванню» 2019, Київ 22-24 травня 2019p.- КПІ імені Ігоря Сікорського http:// immmi.kpi.ua/imm2019/ paper/view/17800

4. Trubachev S. I. Vibrations of lamellar and rod structures with energy dissipation/ Trubachev S. I, Alekseychuk O. N.// Інформаційні системи, механіка та керування: науково-технічний збірник. -2016.- №14- С.98105. DOI: https://doi.org/10.20535/2219-380414201678423 .

5. Trubachev $S$. I. Numerical simulation of bellows compensators stress-strain state in air intake system / S. I. Trubachev, O. N. Alekseychuk // Інформаційні системи, механіка та керування : науково-технічний збірник. 2019.-№21 - стр. 80-85. DOI: https://doi.org/10.20535/2219$\underline{3804212019194279 .}$. 


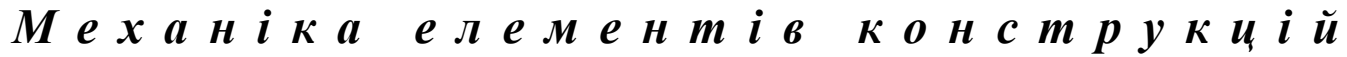

6. Яхно Б. О. Напряжено-деформированное состояние цилиндрических толстостенных перфорированных оболочек / Б. О.Яхно, С. И. Трубачев. // Вісн. НТУУ "КПІ". Машинобудування.. - 2013. C. 126-130.. 